\title{
Factors Affecting the Toxicity of Oxygen Towards Airborne Coliform Bacteria
}

\author{
By J. E. BENBOUGH \\ Microbiological Research Establishment, Porton, Salisbury, Wiltshire
}

(Accepted for publication 24 January 1969)

\begin{abstract}
SUMMARY
The maximum bactericidal effect of oxygen on airborne coliform bacteria occurred at the lowest relative humidity tested. Escherichia coli COMMUNE and Klebsiella aerogenes were very much less sensitive than E. coli $\mathbf{B}$ and $E$. coli JEPP. Only a small partial pressure of oxygen in a nitrogen-oxygen mixture at atmospheric pressure was required to produce the maximum effect. The oxygen toxicity for each bacterial strain was altered by changing the growth conditions or by including certain chemicals in the spray fluid. These chemicals are protective to freeze-dried bacteria and therefore inactivation of oxidative enzymes in freeze dried and airborne bacteria probably occur by similar mechanisms. The same oxidative enzymes in bacterial colonies were slightly inactivated by hyperbaric oxygen pressures.
\end{abstract}

\section{INTRODUCTION}

Cox (1966) and Cox \& Baldwin (1967) showed that Escherichia coli sprayed from distilled water died rapidly in air or in oxygen and that death was very marked at low relative humidity $(\mathrm{RH})$ values. At $\mathrm{RH}$ values above $70 \%$ other death mechanisms prevail (Cox \& Baldwin, 1966; Benbough, 1967) which may be associated with rehydration on collecting the partially dried bacteria.

Past investigations into metabolic disturbances caused by oxygen have been hampered by difficulty in recovering adequate quantities of bacteria from laboratory aerosols. However, comparison of the oxygen effects on freeze-dried bacteria (Lion \& Bergmann, 196r ; Lion \& Avi-Dor, 1963) with those on airborne bacteria and simulation of the aerosolized state by drying bacterial suspensions on filter membranes (Benbough, 1967) have been successful in attempts to elucidate the death mechanisms of airborne bacteria. In dried bacteria enzymes and/or coenzymes concerned with pyruvate degradation and with the reduction of tetrazolium salts were affected. The effect on pyruvate degradation recalled the findings of Thomas, Neptune \& Sudduth (1963) who attributed the toxicity of hyperbaric oxygen on pyruvic oxidase activity to oxidation of the dithiol moiety of $\alpha$-lipoic acid, a cofactor of pyruvic oxidase.

Polyhydroxycompounds have been the most widely used protective agents of aerosolized bacteria (Webb, I960); according to Cox (1966) they protect because they form supersaturated viscous layers around bacteria and thus limit loss of water. An increase in the bacterial polysaccharide content ought then to be beneficial towards aerosol stability by a similar mechanism to the added polyhydroxycompounds; this is reported in this paper. 


\section{METHODS}

Escherichia coli (strains B, JEPP and COMMUNE) and Klebsiella aerogenes (H. 8) were either grown in a chemically defined medium (Benbough, 1967) or in a complex tryptone medium (Anderson, 1966).

Aerosol survival estimation. This was described by Benbough (1967). In tests involving the effect of oxygen concentration the quantities of oxygen were admitted to the drum previously containing pure nitrogen. The bacteria were sprayed with pure nitrogen so the quoted oxygen concentrations in the drum were corrected for the volume displaced by that nitrogen.

Chemicals whose protective ability were being tested were added to the spray fluid before aerosolization.

Polysaccharide content of bacteria. This was expressed as a percentage of the dry weight and was measured as follows. To $\mathrm{I} \cdot 0 \mathrm{ml}$. suspension containing $2 \times 10^{11}$ bacteria/ml. $\mathrm{I} \cdot 0 \mathrm{ml} .5 \%$ redistilled Analar grade phenol was added followed by $5 \cdot 0 \mathrm{ml}$. concentrated sulphuric acid. These were thoroughly mixed and the red colour compared at $545 \mathrm{~m} \mu$ with standard glucose solutions. The dry weight was measured as described by Anderson \& Dark (1966).

Drying and storage of dried bacteria in a controlled $R H$. A bacterial suspension was spread evenly over Oxoid membrane filter (diam. $6 \mathrm{~cm}$.). The culture fluid was drained by suction before placing the membrane filter in a desiccator containing $100 \mathrm{ml}$. of saturated $\mathrm{K}_{2} \mathrm{CO}_{3}$ solution which kept the $\mathrm{RH}$ constant at $44 \%$.

The effect of oxygen on the enzymic activity of dried bacteria. The bacteria-laden membrane filters were stored in either nitrogen, air or oxygen for I hr. Then a small volume of phosphate buffer was used to wash bacteria from the membrane. Each suspension was diluted so that the final bacterial count was approximately $2 \times 10^{10}$ per ml. The utilization of pyruvate was measured as described by Benbough (1967). The rate of reduction of tetrazolium salts was measured by adding to $0.2 \mathrm{ml}$. suspension, $0.5 \mathrm{ml}$. of $5 \%$ triphenyltetrazolium chloride and $3.0 \mathrm{ml}$. of a solution of $0.4 \mathrm{M}-$ sodium malate (or lactate or succinate) dissolved in $9.0 \mathrm{ml}$. of $0.1 \mathrm{M}$-tris at $\mathrm{pH} 8.8$. for malate, 7.4 for lactate or 6.8 for succinate. The tubes were incubated at $37^{\circ}$ for 15 , 30,45 and 60 min. each and formozan formation measured as described by Benbough (1967).

Very little reduced nicotinamide adenine dinucleotide (NADH) oxidase activity could be detected with whole bacteria. Cell-free extracts were prepared by treating Io $\mathrm{ml}$. suspension in 50 mM-tris buffer at $\mathrm{pH} 7 \cdot 4$ by an MSE sonic disintegrator at $0^{\circ}$ for $30 \mathrm{~min}$. at maximum power and centrifuging the resulting suspension at $12,000 \mathrm{~g}$ for $15 \mathrm{~min}$. The NADH oxidase activity of the supernatant fluid was determined as follows: to $0.2 \mathrm{ml}$. supernatant fluid, $2.8 \mathrm{ml}$. of $50 \mu \mathrm{M}$-tris buffer $\mathrm{pH} 7 \cdot 4$ (containing 0.I mM-NADH (B.D.H. Chemicals Ltd., Poole, England) were added and rapidly mixed in a $5 \times \mathrm{I} \times \mathrm{I} \mathrm{cm}$. fused silica spectrophotometer cell. After mixing, the extinction at $340 \mathrm{~m} \mu$ was measured as a function of time on a Unicam spectrophotometer at room temperature.

The effect of oxygen concentration on bacterial colony growth and on activity of enzymes extracted from bacterial colonies on agar surface. About 100 organisms were spread evenly over agar plates which were placed in containers whose oxygen concentration in nitrogen ranged from 0 to $100 \%(\mathrm{v} / \mathrm{v})$ at atmospheric pressure. After 
incubation overnight at $37^{\circ}$ the visible colonies were counted. Bacterial colonies on agar were also exposed to atmospheres of nitrogen, air or oxygen for about $6 \mathrm{hr}$, then they were resuspended in phosphate buffer and pyruvate utilization, formozan production and NADH oxidase activities were measured.

The effect of nitric oxide on the oxygen toxicity of dried bacteria. Immediately after placing bacteria-laden membrane filters in a desiccator at $44 \% \mathrm{RH}$, the vessel was evacuated, filled with pure nitrogen, evacuated again and finally partially filled with nitrogen. A calculated quantity of nitric oxide, formed by mixing sodium nitrite and potassium ferrocyanide in dilute acetic acid within an air-free container, was drawn into the desiccator by negative pressure via a soda lime tube; the pressure was restored to atmospheric by adding more pure nitrogen. After $15 \mathrm{~min}$. the filter was removed from the desiccator into air, was well ventilated to limit contact with nitrogen dioxide, and transferred to another vessel containing air at $44 \% \mathrm{RH}$. The survival of dried bacteria which received the above treatment was compared with controls which did not receive the nitric oxide treatment.

\section{RESULTS}

Figure I shows that at $70 \% \mathrm{RH}$ similar survivals were obtained for storage in air or nitrogen. At low RH the survival in nitrogen was much greater than in air or in a $20 \%(\mathrm{v} / \mathrm{v})$ oxygen $+80 \%(\mathrm{v} / \mathrm{v})$ nitrogen mixture at atmospheric pressure in which the survivals were similar. Therefore, oxygen must be the toxic atmospheric component towards airborne coliform bacteria. Figure 2 shows that there was a considerable

Table I. The influence of growth media on the survival of coliform bacteria sprayed and stored into air at $40 \% \mathrm{RH}$ for $30 \mathrm{~min}$.

\begin{tabular}{|c|c|c|}
\hline & \multicolumn{2}{|c|}{ Growth medium } \\
\hline & $\begin{array}{c}\text { Chemically } \\
\text { defined } \\
\text { Surv }\end{array}$ & $\begin{array}{l}\text { Complex } \\
\text { tryptone } \\
(\%)\end{array}$ \\
\hline Escherichia coli в & $1 \cdot 3$ & I6 \\
\hline E. coli JEPP & $2 \cdot 2$ & $5 \cdot 1$ \\
\hline E. coli COMMUNE & 33 & 55 \\
\hline Klebsiella aerogenes & 22 & 53 \\
\hline
\end{tabular}

variation in the sensitivity of different coliform strains to oxygen. Figure 2 shows that the increase in this sensitivity was directly related to the decrease in the test RH between 70 and $30 \%$.

The results in Figs. I and 2 were obtained from tests on washed bacteria which were originally grown on chemically defined media. Bacteria grown in this way survived less well at low relative humidities than corresponding strains grown in complex tryptone media (Table $\mathrm{I}$ ).

The maximum death rate occurred within the first second of spraying into either 

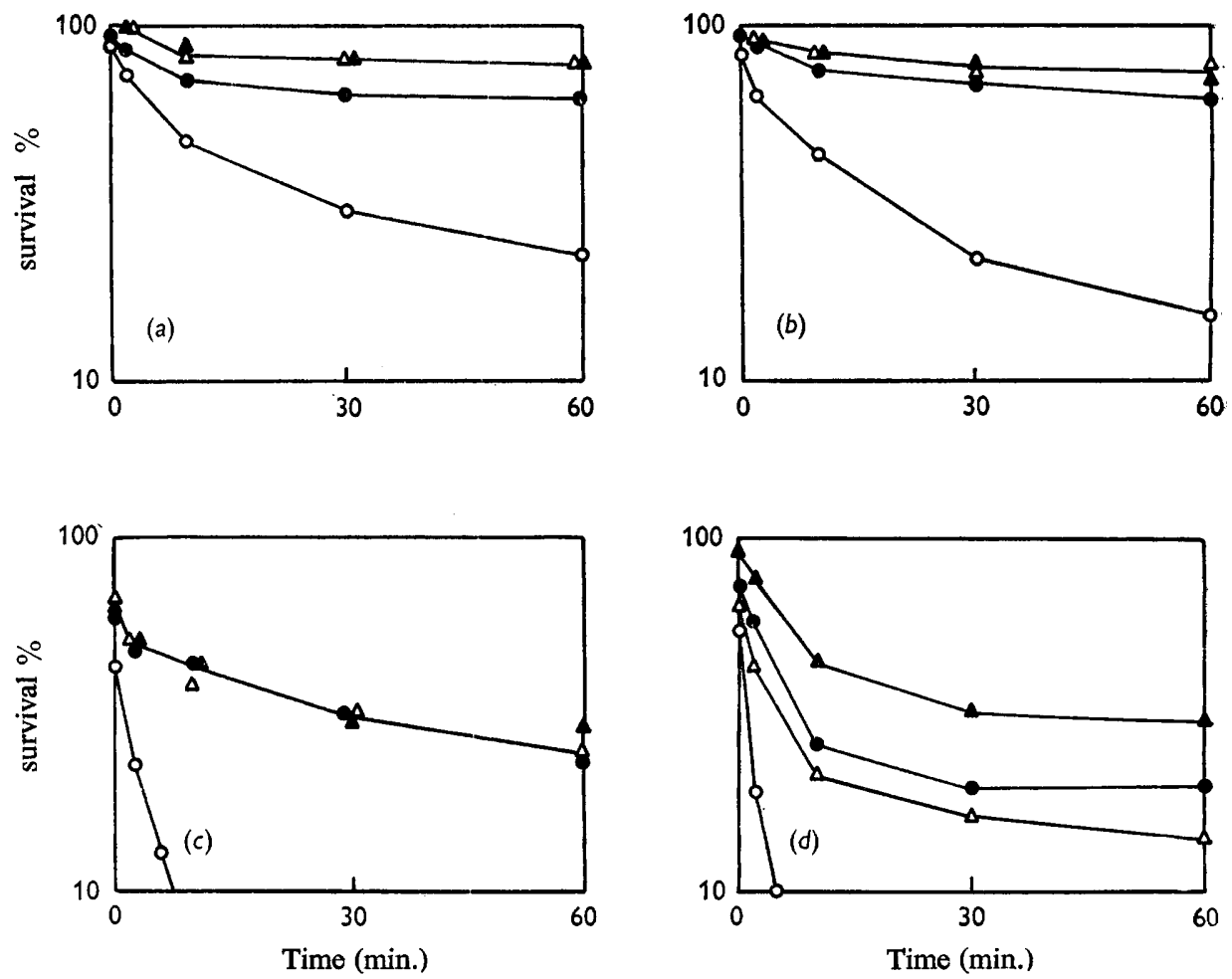

Fig. I. Death rates of aerosolized: (a) Escherichia coli commune, (b) Klebsiella aerogenes, (c) E. coli (JEPP), (d) E. coli B which was sprayed into nitrogen at $70 \% \mathrm{RH}(\boldsymbol{\Delta}-\mathbf{\Delta})$; sprayed into air at $70 \% \mathrm{RH} \triangle-\triangle$; sprayed into nitrogen at $40 \% \mathrm{RH}$ (O-O); sprayed into air at $40 \%$ RH (O-O).

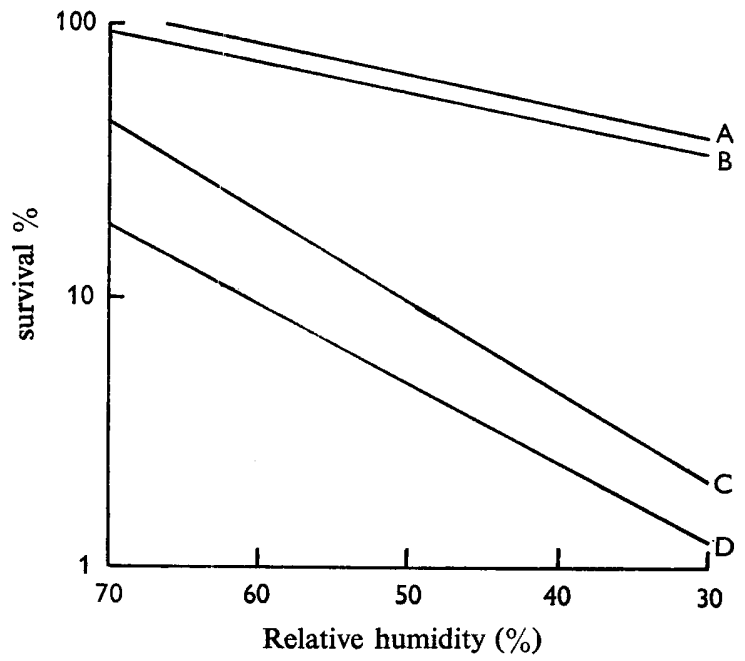

Fig. 2. Survivals of aerosolized bacteria in air as a function of RH (aerosol age Io min.). A, Escherichia coli COMMUNE; B, Klebsiella aerogenes; C, E. coli (JEPP); D, E. coli B. Each of the above straight lines represents between 15 and 25 experimental points. 
air or nitrogen but was fastest in air at low RH. Also, at low RH the secondary death rates in air did not tend to become zero as compared to those in nitrogen or air at high $\mathrm{RH}$ values (Fig. I). Figure 3 shows that bacteria sprayed and stored in nitrogen for $0.4 \mathrm{sec}$. before exposure to air were more sensitive to air than those sprayed directly into air in otherwise similar conditions. Small additions of oxygen to nitrogen atmospheres induced large increases in the death rate; the maximum death rate was reached by fairly low oxygen concentrations in nitrogen (Fig. 4).

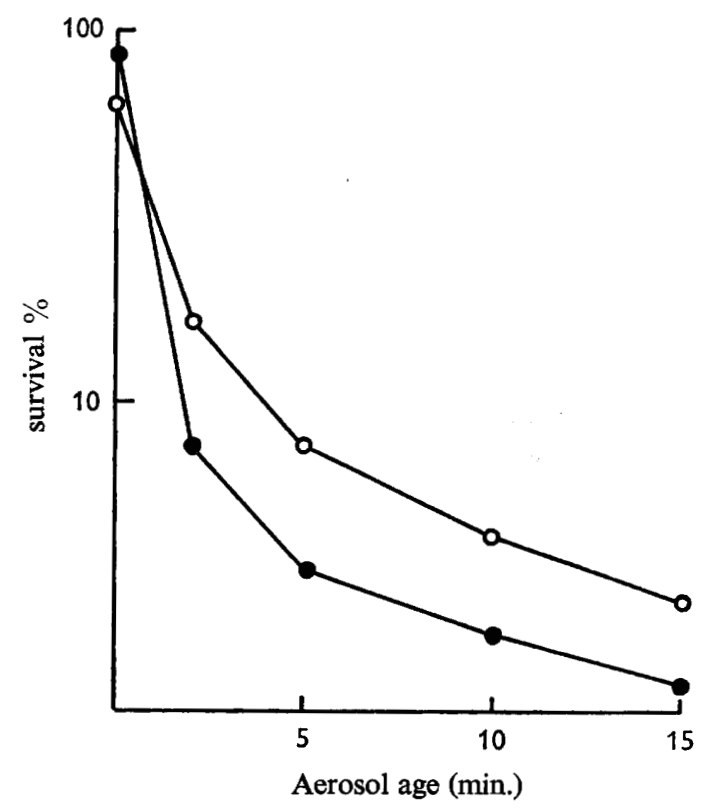

Fig. 3. The deleterious effect of spraying Escherichia coli B into nitrogen before being passed into and stored in air at 50\% RH: $\bigcirc-\mathrm{O}$, bacteria sprayed into air and stored in air; bacteria sprayed into nitrogen and stored in air after aerosol age of $0.4 \mathrm{sec}$. In the above figure the survival given at $0 \mathrm{~min}$. is in fact the survival at $0.4 \mathrm{sec}$.
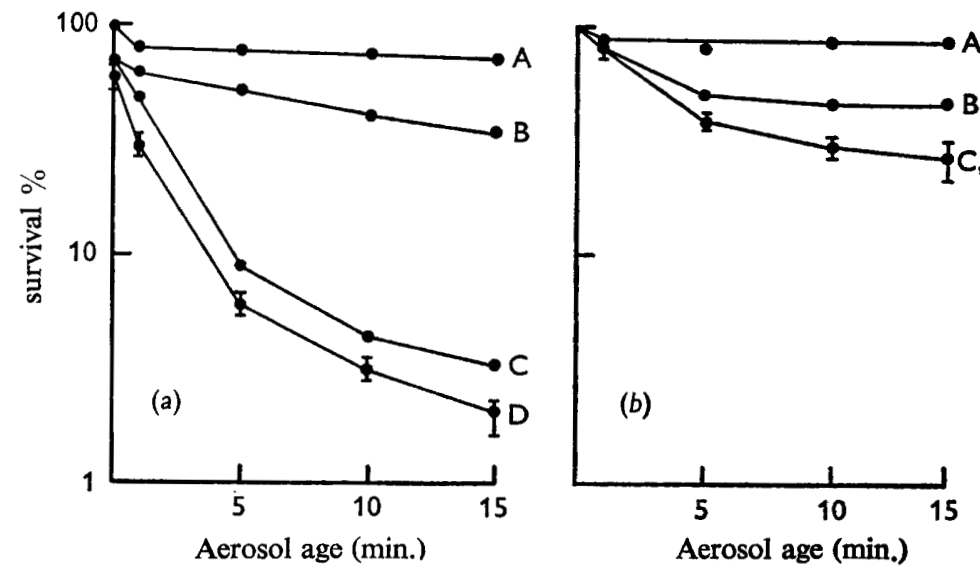

Fig. 4. Effect of oxygen concentration on death rate of aerosolized Escherichia coli B sprayed into nitrogen and stored in nitrogen-oxygen mixtures at $(a) 50 \% \mathrm{RH} ;(b) 70 \% \mathrm{RH} ; \mathrm{A}, p \mathrm{O}_{\mathbf{2}}$ is 0.00 atmosphere; $B$ is $0.03 \mathrm{~atm} ; \mathrm{C}$ is $0.36 \mathrm{~atm} ; \mathrm{D}$ is $0.60,1.20,3.00$ and $4.50 \mathrm{~atm}$. 
Table 2. The effect of some compounds included in the spray fluid on the survival of aerosolized Escherichia coli $B$ at $50 \% R H$

Compound

Distilled water*

Distilled water*

Thiourea

$\mathrm{KNO}_{2}$

$\mathrm{KI}$

KCNS

2-aminoresorcinol

Methylene blue

Thymolindophenol

Ascorbic acid

(pH to $7^{\circ} \circ$ with $\left.\mathrm{NaOH}\right)$

Catalase

$\mathrm{H}_{2} \mathrm{O}_{2}$

Raffinose

Raffinose

Glucose

Sucrose

Glycerol

Glycerol

$\mathrm{MnCl}_{2}$

$\mathrm{MnSO}_{4}$

$\mathrm{CoCl}_{2}$

$\mathrm{ZnCl}_{2}$

$\mathrm{KCl}$

$\mathrm{MgCl}_{2}$

$\mathrm{MgSO}_{4}$

\begin{tabular}{|c|c|c|c|c|}
\hline \multirow{3}{*}{$\begin{array}{l}\text { Concentration } \\
(\mathrm{mM})\end{array}$} & \multicolumn{4}{|c|}{ Aerosol age (min.) } \\
\hline & \multirow{2}{*}{$\overbrace{85}^{I}$} & \multicolumn{2}{|c|}{$2 \begin{array}{r}5 \\
\\
\end{array}$} & IO \\
\hline & & 80 & 80 & 76 \\
\hline & 32 & 14 & 6 & 3 \\
\hline 0.7 & 68 & 59 & $5 \mathrm{I}$ & 45 \\
\hline 0.5 & 43 & $3 I$ & 24 & 24 \\
\hline 0.3 & 42 & 38 & 35 & 35 \\
\hline$I \cdot 2$ & 40 & 32 & 18 & 15 \\
\hline 0.3 & 58 & 38 & 22 & 20 \\
\hline $0.05-5.0$ & 42 & 20 & 6 & $\mathbf{I}$ \\
\hline $0.05-5.0$ & 29 & 5 & I & - \\
\hline$I \cdot 2$ & 45 & 22 & 12 & 9 \\
\hline $0.01 \%$ & 38 & 16 & 10 & 5 \\
\hline $2 \cdot 0$ & 35 & 13 & 9 & 5 \\
\hline 300 & 68 & 62 & 40 & 20 \\
\hline $3 \cdot 0$ & 30 & I6 & 4 & 3 \\
\hline $2 \cdot 8$ & 31 & 10 & 4 & 2 \\
\hline $2 \cdot 8$ & 38 & 20 & 6 & 3 \\
\hline 2.5 & 29 & 12 & 5 & 4 \\
\hline 250 & 48 & 42 & 26 & 16 \\
\hline 0.4 & 40 & 24 & 19 & 12 \\
\hline 0.5 & 48 & 35 & 24 & 16 \\
\hline 0.2 & 37 & 21 & 15 & I0 \\
\hline 0.4 & 30 & 10 & 5 & I \\
\hline 0.5 & $3 I$ & 10 & 3 & I \\
\hline 0.4 & 32 & 18 & 8 & 6 \\
\hline 0.6 & 37 & 23 & 9 & 7 \\
\hline
\end{tabular}

* Sprayed into $\mathrm{N}_{2}$; all others sprayed into air.

Table 3. Polysaccharide contents of coliform bacteria grown in various chemically defined media

$\begin{array}{lcc}\text { Strain } & \begin{array}{c}\text { Growth } \\ \text { medium }\end{array} & \begin{array}{r}\text { Polysaccha } \\ \text { dry weig }\end{array} \\ \text { ia coli B } & a & 0.13 \\ \text { ia coli coMMUNE } & a & 0.23 \\ \text { a coli JEPP } & a & 0.10 \\ \text { aerogenes } & a & 0.22 \\ & b & 0.23 \\ \text { ia coli B } & c & 0.19 \\ \text { a coli COMMUNE } & b & 0.38 \\ \text { aerogenes } & b & 0.42\end{array}$

$a$, denotes the chemically defined medium described in Methods.

$b$, denotes the above medium except that the ammonium citrate concentration was decreased to $50 \mu \mathrm{g} . / \mathrm{ml}$.

$c$, denotes the above medium except that the magnesium sulphate concentration was decreased to $0.24 \mu \mathrm{g} . / \mathrm{ml}$. 
The death rate of bacteria in the aerosol at low RH is decreased when certain chemicals are included in the spray fluid (Benbough, 1967; Cox, 1966). The protective effects of more chemicals are listed in Table 2; most of these were effective in millimolar quantities. Redox dyes were tested because in the reduced form their ability to combine with oxygen might limit death in the aerosol. Methylene blue decreased the initial death rate substantially, but the secondary death rate was accelerated; thus it appeared to delay the toxic effect of oxygen. Thiourea, ascorbic acid, 2 aminoresorcinol, like cysteamine (Benbough, 1967), protected aerosolized bacteria at low RH only; these compounds were toxic between 60 and $80 \% \mathrm{RH}$. In contrast to the protective compounds already described, sugars and other polyhydroxycompounds were needed in high concentrations to protect aerosolized bacteria. Catalase did not protect, hence toxic amounts of $\mathrm{H}_{2} \mathrm{O}_{2}$ were not produced; $\mathrm{H}_{2} \mathrm{O}_{2}$ included in the spray fluid was not toxic.
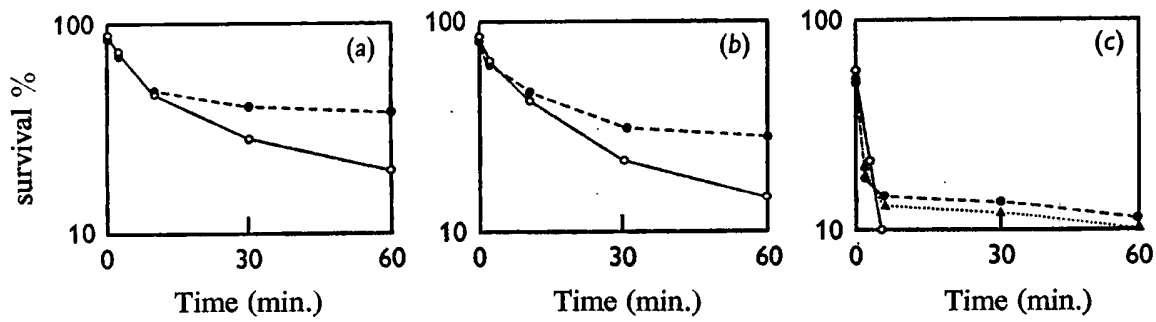

Fig. 5. Death rates of aerosolized: (a) Escherichia coli comMUNE; (b) Klebsiella aerogenes; (c) E. coli B sprayed into air at $40 \% \mathrm{RH}$. $\bigcirc-\bigcirc$, Bacteria grown on chemically defined media as described in Methods; - - bacteria grown in the same medium except that the ammonium citrate was reduced to $50 \mu \mathrm{g} . / \mathrm{ml}$.; $\boldsymbol{\Delta}-\boldsymbol{\Lambda}$, bacteria grown in the same medium except that the $\mathrm{MgSO}_{4}$ was decreased to $0.24 \mu \mathrm{g} . / \mathrm{ml}$.

Strains of coliform bacteria with the higher polysaccharide content can withstand the oxygen effect much better in the aerosol (Table 3). By increasing the polysaccharide content of each strain by growing and incubating in carbon-rich and nitrogen- or magnesium-limiting media (Wilkinson, 1959), the following result was obtained: the initial death rate was as fast as corresponding strains grown on the complete defined medium but the secondary death rate was considerably slower (Fig. 5).

Enzymes concerned with reduction of $2: 4: 6$-triphenyl tetrazolium chloride, NADH oxidase and pyruvate degradation were inactivated by oxygen in partially dried bacteria (Table 4). Results on Table 4 also show that hyperbaric oxygen inactivated the same enzymes in bacterial colonies. The effects of oxygen on partially dried bacteria and on colonies may therefore be basically the same; however, much higher oxygen concentration was needed to produce the same effect in the latter case. Double atmospheric oxygen pressure produces a threshold bacteriostatic effect on Escherichia coli colonies whilst five times atmospheric oxygen pressure causes $50 \%$ and $30 \%$. inhibition of colony formation from single $E$. coli B and E. coli COMMUNE bacteria respectively.

When partially dried bacteria on membrane filters were exposed to nitric oxide for a few minutes before exposure to oxygen the number of bacteria killed was greatly diminished. The maximum protective effect was produced by 50 parts per million nitric oxide in nitrogen (Table 5). 
Table 4. The inactivation of three bacterial enzyme systems by oxygen

(a) Enzymes concerned with the utilization of pyruvate

$$
\begin{gathered}
\text { Uptake of pyruvate } \\
\text { by suspension } \\
\mu \mathrm{M} / \mathrm{min} . / 10^{10} \\
\text { breatment } \\
\text { bacteria }
\end{gathered}
$$

$E$. coli B dried at $44 \% \mathrm{RH}$ for I hr at I atm. in

Nitrogen

Oxygen

Air

$3 I \pm I$
$2 I \pm I$
$22 \pm I$
$33 \pm I$
$28 \pm I$
$33 \pm I$

$E$. coli B colonies exposed for $\mathrm{I} 8 \mathrm{hr}$ at $\mathrm{I}$ atm. in

Nitrogen

Oxygen

Air

$33 \pm$

(b) Enzymes concerned with the reduction of 2:4:6-triphenyltetrazolium chloride to formozan

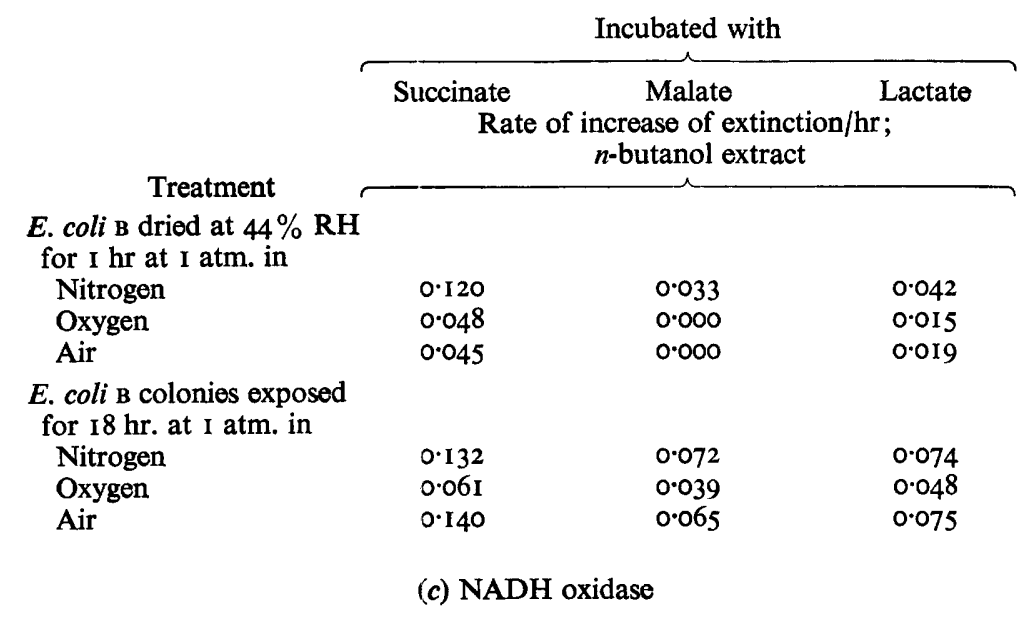

Activity n-mole

Treatment NADH oxidized $/ \mathrm{min}$.

E. coli B dried at $44 \% \mathrm{RH}$

for I hr at I atm. in

$\begin{array}{lr}\text { Nitrogen } & 190 \pm 10 \\ \text { Oxygen } & 90 \pm \text { 10 } \\ \text { Air } & \text { I IO } \pm \text { 10 }\end{array}$

E. coli COMMUNE dried at

$44 \%$ RH for I hr at I atm. in

Nitrogen

Oxygen

$140 \pm 10$

$90 \pm 10$

Air

$90 \pm 10$

$E$. coli B colonies exposed

for $18 \mathrm{hr}$ at $\mathrm{I}$ atm. in

Nitrogen

$220 \pm 10$

Oxygen

$130 \pm 10$

Air

$230 \pm 10$ 
Table 5. Effect of nitric oxide on the survival of dried

Escherichia coli $B$ at $44 \%$ RH exposed to air

$\begin{array}{cc}\text { NO conc. p.p.m. } & \begin{array}{c}\text { Proportion of } \\ \text { bacteria surviving } \\ \text { at I atm. }\end{array} \\ \begin{array}{c}\text { exposure to air } \\ \text { after }\end{array} \\ 0 & 0.3 \pm 0.1 \\ \text { I0 } & 0.5 \pm 0.2 \\ 50 & 0.6 \pm 0.2 \\ 60 & \text { Less than } 0.001 \\ 100 & 0\end{array}$

\section{DISCUSSION}

The lethal action of oxygen appears to depend on the loss of water from bacteria. Bateman, Stevens, Mercer \& Carstensen (1962) measured the water content of Serratia marcescens at many $\mathrm{RH}$ values and found that it decreased rapidly between $100 \%$ and $70 \% \mathbf{R H}$, but below $70 \%$ the decrease was very much less. This shows that strongly bound water is lost when bacteria are exposed to RH values of $70 \%$ and less. Bound water has a structural significance and its loss may cause changes in accessibility and reactivity of macromolecules. Freeze-dried Escherichia coli show electron spin-resonance signals (Dimmick, Heckley \& Hollis, 196r; Lion, Kirby-Smith \& Randolph, I96I; Lion \& Bergmann, I96I); these signals are emitted by free radicals and the signals were greatly enhanced when the freeze-dried bacteria were exposed to oxygen, presumably because paramagnetic molecules such as oxygen react readily with free radicals to form peroxyradicals. Such events probably occur when bacteria are sprayed into air at low $\mathbf{R H}$ values. The peroxyradicals formed in this way would inactivate many of the oxidative enzymes. Protection by nitric oxide can be explained by its paramagnetic character: it would react with free radicals formed during bacterial hydration and thus prevent peroxyradical formation.

Airborne bacteria can be protected in two ways. First, polyhydroxy compounds limit the loss of water from bacteria in the same way as those bacterial strains that possess a high polysaccharide content. Secondly, other compounds may act directly on the oxygen inactivating site; these compounds are effective in micromolar quantities and they include paramagnetic ions such as $\mathrm{Mn}^{2+}, \mathrm{NO}_{2}{ }^{-}, \mathrm{I}^{-}$and compounds with labile hydrogens such as ascorbic acid, aminothiols and reduced dyes.

Comparison of the extent of enzyme inactivation in bacterial colonies by hyperbaric oxygen to inactivation in dried bacteria by air confirms the role of cellular water in limiting oxygen toxicity.

The author thanks Dr C. E. Gordon Smith and Mr I. H. Silver for their helpful discussion, and Mrs J. Rice for technical assistance.

\section{REFERENCES}

ANDERson, J. D. (1966). Biochemical studies of lethal processes in aerosols of Escherichia coli. J. gen. Microbiol. 45, 303.

Anderson, J. D. \& DARK, F. A. (1966). Studies on the effects of aerosolization on the rates of efflux of ions from populations of Escherichia coli strain B. J. gen. Microbiol. 46, 95. 
Bateman, J. B., Stevens, C. L., Mercer, W. B. \& Carstensen (1962). Relative humidity and the killing of bacteria: the variation of cellular water content with external relative humidity or osmolarity. J. gen. Microbiol. 29, 207.

BenBough, J. E. (1967). Death mechanisms in airborne Escherichia coli. J. gen. Microbiol. 47, 325.

Cox, C. S. (1966). The survival of Escherichia coli atomized into air and into nitrogen from distilled water and from solutions of protecting agents, as a function of relative humidity. J. gen. Microbiol. 43, 383 .

Cox, C. S. \& BALDwIN, F. (1966). The use of phage to study causes of loss of viability of Escherichia coli in aerosols. J. gen. Microbiol. 44, 15.

Cox, C. S. \& BALDWIN, F. (1967). The toxic effect of oxygen upon the aerosol survival of Escherichia coli B. J. gen. Microbiol. 49, 115.

Dimmick, R. L., Heckley, R. S. \& Hollis, D. P. (196I). Frøe radical formation during storage of freeze dried Serratia marcescens. Nature, Lond. 192, 776.

LIon, M. B. \& AvI-DoR, Y. (1963). Oxygen-induced inactivation of NADH-oxidase in lyophilized cells of Escherichia coli. Israel J. Chem. I, 374.

Lion, M. B. \& Bergmann, E. D. (1961). The effect of oxygen on freeze-dried Escherichia coli. J. gen Microbiol. 24, 191.

Lion, M. B., KIRBY-SmITH, J. S. \& RANDOLPH, M. L. (196I). Electron spin resonance signals from lyophilized cells exposed to oxygen. Nature, Lond. 192, 34.

Thomas, J. J., NePTUNe, E. M. \& SudDUth, H. C. (1963). Toxic effect of oxygen at high pressure on the metabolism of D-glucose by dispersions of rat brain. Biochem. J. 88, 31 .

WeBB, S. J. (1960). Factors affecting the viability of airborne bacteria. II. The effect of chemical additions on the behaviour of airborne cells. Can. J. Microbiol. 6, 71.

WiLkINson, J. F. (1959). The problem of energy-storage compounds in bacteria. Expl Cell. Res. Suppl. 7, III. 